\title{
Polygenic Association of $A C E$ and ACTN3 Polymorphisms with Korean Power Performance
}

\section{Chul-Hyun Kim*}

\section{Exercise Sport Science Institute, Korea National Sport University, Seoul 138-763, Korea}

Received January 31, 2012 /Revised March 8, 2012 /Accepted March 8, 2012

\begin{abstract}
This study aimed to examine whether the polygenic profile of $A C E I D$ and ACTN3 R577X polymorphisms is associated with muscle power performance in Korean athletes. For this study, 106 top-class power athletes (top-class group), 158 elite power athletes (elite-class group), and 676 healthy adults (control) aged 18-39 yrs were recruited and their genotypes were analyzed. The top-class group showed higher frequencies of the $I I$ genotype and $I$ allele in $A C E$, as well as higher frequencies of the $R R$ genotype and $R$ allele in $A C T N 3$ (top-class vs. control: $41.4 \%$ vs. $32.1 \%$ for $I I$ genotype, $67.1 \%$ vs. $57.7 \%$ for $I$ allele, $p<0.05 ; 42.3 \%$ vs. $29.0 \%$ for $R R$ genotype, $65.3 \%$ vs. $54.8 \%$ for $I$ allele, $p<0.05$ ). In the polygenic profile, the top-class group had significantly higher frequencies of combined-II/ID+RR/RX genotype than the control group (top-class vs. control: $82.9 \%$ vs. $66.7 \%$ for II/ ID+RR/RX, $<0.05)$, and there was even a sharp increase in total genotype score (TGS) in this group compared to the elite-class and control groups ( $66 \pm 0.9$ vs. $58 \pm 1.9$ vs. $56 \pm 2.3, p<0.05)$. The combined-II/ ID+RR/RX genotype showed the possibility of succussion in the top-class muscle power performance with an odds ratio of 2.3 (CI:1.4-4.1, $p<0.05$ ). These results suggested that $A C E$ and $A C T N 3$ need to interact with each other to affect muscle-power performance in an additive form. Furthermore, the polygenic profile of $A C E$ and $A C T N 3$ can predict muscle performance with high success in a homogeneous dominant combined genotype $(I I / I D+R R / R X)$. A further study could identify and combine other genes into $A C E$ and $A C T N 3$ for muscle strength.
\end{abstract}

Key words : Muscle power, genetic traits, a-actinin-3, angiotensin-converting enzyme

\section{서 론}

근력은 골격근이 단기간 최대의 힘을 동원하여 수축하는 능력으로, 건강관련 체력에 중요한 요인일뿐아니라, 대다수의 스포츠종목에서는 반드시 요구되는 필수적인 체력요인이다 [27]. 근력은 환경적 요인과 함께 유전적 요인에 의해서 정해진 다. 특히, 근력의 $60 \%$ 이상이 유전적 요인에 결정된다. 따라서 개인의 타고난 체력적 재능과 훈련에 따른 민감도의 차이는 유전자에 의해서 조절된다[1,26]. 현재까지 다수의 유전자 중 에서 근력의 잠재적 특성과 민감도를 조절하는 유전자로 $A C E$ $I / D$ 다형성과 ACTN3 R577X 다형성이 크게 주목받고 있다 $[12,28,29,47]$.

$A C E$ I/ $D$ 다형성은 인간의 염색체 $17 \mathrm{q} 23$ 에 위치하는 $A C E$ 유전자 안에 16 번 인트론(intron) 부위에 $287 \mathrm{bp} \mathrm{Alu}$ 염기서열 이 삽입(Insertion: $I$ allele) 또는 결손(Deletion: $D$ allele)으로 $I I, I D, D D$ 유전형이 나타나는 유전자 다형성이다[31,41]. 인체 에서 $D D$ 유전형은 $I I$ 유전형 보다 3 배정도 높은 안지오텐신전 환효소(angiotensine-converging enzyme: $\mathrm{ACE}$ ) 활성도를 가 진다. 그리고 $I D$ 유전형은 중간수준을, $I I$ 유전형은 낮은 안지

*Corresponding author Tel : +82-2-410-6700, Fax : +82-2-410-6945

E-mail : kimch37@gmail.com
오텐신전환효소(ACE) 활성도를 가진다[22]. 안지오텐신-전환 효소 $(\mathrm{ACE})$ 는 조직특이적으로 골격근에서 단백질 합성을 억 제시키고, 단백질 분해를 촉진하는 역활을 한다 $[2,3,4,37,40]$. 따라서 안지오텐신전환효소(ACE)의 활성도가 높은 $D D$ 유전 형은 높은 안지오텐신전환효소(ACE) 활성도의 작용으로 인 해 골격근의 성장과 재생을 지연시켜서 근력의 발달을 제한한 다. 반면, $I I$ 유전형과 $I D$ 유전형은 낮은 안지오텐신전환효소 $(\mathrm{ACE})$ 활성도의 작용으로 인해 골격근의 합성을 유도하여 근 력 발달에 유익한 작용을 한다. 이와 관련하여 $A C E$ 유전형에 따라 근력훈련에 따른 근비대와 근력 향상, 근력관련 운동경 기력에 영향을 미치는 것으로 보고되었다[16,23,43]. 따라서 $A C E$ 다형성은 근력의 잠재적 특성과 민감도를 결정할 수 있 는 유전자로 주장되고 있다[16,28,29,23,43].

한편, $A C T N 3$ R577X 다형성도 역시 근력관련 유전자 다형 성으로 주목고 있다[12,47]. $A C T N 3$ R577X 다형성은 인간의 염색체 $11 \mathrm{q} 14$ 에 존재하는 $A C T N 3$ 유전자의 16 번 exon내 1,747 번째 염기가 $\mathrm{C}$ 또는 $\mathrm{T}$ 로 전이하여 $R R, R X, X X$ 유전형을 가진 다[25]. $R R$ 유전형과 $R X$ 유전형은 a-actinin-3가 속근섬유에만 제한적으로 발현되어 속근의 최대 수축력뿐아니라 무산소성 에너지대사의 조절에도 관여한다. 반면, $X X$ 유전형은 $\mathrm{a}$ -actinin-3의 발현이 차단되어, 지근섬유에서 발현되는 $a$ -actinin-2가 속근 섬유에서 발현되는 보상작용을 한다[21]. 골 
격근의 속근섬유에서만 기능적 역할을 하는 a-actinin- 3 의 발 현과 억제는 속근섬유내 근절의 구조적 - 기능적 변이로 인한 근수축 작용의 차이를 가져온다. 즉, $A C T N 3$ 의 유전적 소인에 의해 선천적인 근수축 능력이 정해지며, $A C T N 3$ 의 유전적 소 인은 최대 근수축력에 영향을 미치기 때문에, $A C T N 3$ 는 무산 소파워성 근력의 능력을 결정하는 중요한 유전자로 주장된다 [47-49]. 이와 관련하여 ACTN3 R577X 다형성 중에서 a -actinin-3를 발현하는 $A C T N 3 R R$ 유전형은 근력관련 운동종 목의 선수들에서 높은 빈도로 발견되었고, 근력 훈련에 따른 적응도 역시 높게 나타났다. 또한 ACTN3 R577X 다형성에 따 라 근육량이 결정될 수 있다는 연구들이 추가적으로 보고되었 다 $[5,6,8,26,33,45,48]$. 따라서, $A C T N 3$ R557X 다형성 역시 근력 을 결정하는 유전적 인자로 주목되어 많은 연구가 보고되어 왔다[12,26,33,45,47,48].

그러나 그 동안의 연구결과는 아직 일반화 하기에 부족 하다. 특히, 인종적 차이를 가지는 유전적 특성을 한국인에 게 적용하는데는 아직 미흡하여, 한국인에서 이 두 유전자 가 근력과 관계가 있는지를 확인할 필요가 있다. 무엇보다 도 근력에 대한 유전적 요인은 단일유전자의 영향 보다는 다중유전자에 의해서 결정된다[14,29]. 그렇지만 이제까지의 연구는 단일 유전자에만 국한되었고, 최근 일부 연구에서 다수의 유전자를 조합하여 체력에 대한 유전적 설명력을 이 해하기 위한 시도들이 보고되었다 $[34,39,44]$. 근력 및 체력의 유전적 특성은 다중유전자의 조합에 의해 결정될 수 있으므 로, 단일유전자보다 다중유전자가 근력에 대한 유전적 소인 을 보다 긴밀히 설명할 수 있다[14,34,44,39]. 그럼에도 불구 하고 아직까지 근력과 관련된 다중유전자에 대한 연구 및 정보는 거의 미비한 실정이다.

따라서, 본 연구는 국내 한국인에서 적용할 수 있는 근력관 련 유전적 정보를 근력운동 경기력에 따른 단일유전자적 수준 과 다중유전자적 수준에서 모두 얻고자 한다. 이에 따른 연구 의 목적은 $A C E$ 와 $A C T N 3$ 유전자가 단일 유전자 수준과 다중 유전자 수준에서 근력운동종목의 경기력에 관계하는 수준을 구명하는데 있다.

\section{재료 및 방법}

\section{연구 대상}

이 연구는 유전자 다형성에 따른 근력에 관여되는 수준이 단일 및 다중 유전자 수준에서 관계되는가를 규명하기 위해 수행되었다. 연구의 목적을 위해 최대의 운동단위를 신속하게 동원하여 근수축을 발휘하는 근력을 대표하는 운동종목의 엘 리트선수 153 명(남자 104명, 여자 49명)과 국가대표선수 111명 (남자 70명, 여자 41명)을 선정하였다. 그리고 대조를 위한 일 반인 676명(남자 358명, 여자 318명)이 참여하였다. 엘리트선 수는 선수경력이 5년이상으로 국내대회에서 몇 차레 입상한
실정이 있는 경력자들이었으며, 국가대표선수는 운동경력이 5 년 이상으로 국가대표에 선발되어 국제대회에 참가한 top-class의 경력자였다. 참여된 선수들의 운동종목은 근력을 대표하는 종목으로 Yang 등[48]이 정의한 종목을 근거로 실행 하였다. 이 결과, 스프린터 $(\leq 400 \mathrm{~m}$ 달리기, $\leq 1,500 \mathrm{~m}$ 스피드 스케이팅), 도약, 투척, 역도 종목이 포함되었다. 일반인은 근 골격근 질환이 없는 외관상 건강한 성인이었다. 모든 연구대 상자는 18 세에서 39 세의 연령대에서 선발되었다. 참여한 연구 대상자는 사전에 연구에 대한 충분한 설명과 이해를 구한 후, 동의를 얻어 연구에 참여하도록 하였다. 이 연구는 을지대학 교 의과대학 연구윤리위워회(IRB)의 윤리심사에 대한 연구허 가와 동의서를 받아서 수행하였다.

\section{유전자 다형성 분석}

채혈 및 $\mathrm{gDNA}$ 추출: 유전자 다형성의 분석을 위해 혈액의 백혈구에 존재하는 genomic DNA를 Puregene® DNA Purification Kit (Catalog-D550, Gentra, USA)를 이용하였다 추

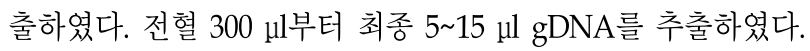

$\mathrm{ACE}$ 다형성 분석: 추출된 $\mathrm{gDNA}$ 로 부터 $A C E \mathrm{ID}$ 다형성 (rs1799752)을 분석하기 위해서 MGB TaqMan® $\mathrm{SNP}$ Genotyping assay 방법을 이용했다. 이 분석방법에 사용된 probe와 primer는 Koch, et al[Koch, 2005]이 개발한 3종의 primer와 2종의 probe를 사용했다. 염기서열은 다음과 같다. Primer ACE111: 5'-CCC-ATC-CTT-TCT-CCC-ATT-TCT-C-3', Primer ACE112: 5'-AGC-TGG-AAT-AAA-ATT-GGC-GAAAC-3', Primer ACE111: 5'-CCT-CCC-AAA-GTG-CTG-GGATTA-3', VIC-ACE100: VIC-5' AGG-CGT-GAT-ACA-GTC-A3'-MGB, FAM-ACE100: FAM-5'TGC-TGC-CTA-TAC-AGTCA-3'MGB. $A C E I D$ 다형성에서 $I$ 대립형질은 위의 primer와 probe 중에서 ACE111 (Forward), ACE112 (Reverse)와 VIC probe에 의해 증폭이 되었으며, $D$ 대립형질은 $\mathrm{ACE} 111$ (Forward), ACE113 (Reverse)와 FAM probe에 의해 증폭이 되었다. 유전자 증폭은 TaqMan Genotyping Assay용 Master Mix를 gDNA 10 50 ng, 150 pmol primer, $150 \mathrm{nM}$ VIC probe, $50 \mathrm{nM}$ FAM probe를 조제하여 35 cycles로 denaturation $92^{\circ} \mathrm{C}$ 15 초, Annealing과 Extension을 $57^{\circ} \mathrm{C} 1$ 분으로 $\mathrm{ABI} 7900 \mathrm{HT}$ (Applied Biosystems Incooperate, USA)에서 증폭하여 유전 자형을 확인했다.

$A C T N 3$ R577X 다형성 분석: 추출된 $\mathrm{gDNA}$ 로 부터 $A C T N 3$ R577X 다형성(rs1815739)을 분석하기 위해서 MGB TaqMan® SNP Genotyping assay 방법을 이용했다. 유전자 증폭을 위한 primer는 custom-designed primer로 Gene Bank로부터 얻어 진 $A C T N$ 염기서열을 $\mathrm{ABI}$ 사에 의뢰해 $R$ allele과 $X$ allele이 인식될 수 있는 primer 사이의 SNP를 포함한 TaqMan probes 를 제작하였다. 염기서열은 다음과 같다. Forward: 5'ACGATC-AGT-TCA-AGG-CAA-GGC-AAC-ACT-3', Reverse: 5'- 
ACC-CTG-GAT-GCC-CAT-GAT-G-3', VIC ( $R$-allele specific probe): 5'-TCG-CTC-TCG-GTC-CCA-TGA-TG-3'MGB, FAM ( $X$-allele specific probe): $5^{\prime}$-TCG-CTC-TCG-GTC-AGC- $3^{\prime}$ MGB. 유전자 증폭은 TaqMan Genotyping Assasy용 Master Mix를 gDNA 10 50 ng, 150 pmol primer, $70 \mathrm{nM}$ VIC probe, $70 \mathrm{nM}$ FAM probe를 조제하여 40 cycles로 denaturation $92^{\circ} \mathrm{C}$ 15초, Annealing과 Extension을 $57^{\circ} \mathrm{C}$ 1분으로 $\mathrm{ABI} 7900 \mathrm{HT}$ (Applied Biosystems Incooperate, USA)에서 증폭하여 확인했다.

\section{다중유전자 조합(Total Genotype Score: TGS)}

$A C E$ 와 $A C T N 3$ 다형성을 조합하여 $A C E-A C T N 3$ 다중유전 자가 근력운동의 경기력에 영향을 주는지를 분석하고자 하였 다. 다중유전자를 위한 조합 방법은 Williams \& Folland[46]와 Santiago 등[39]이 소개한 Total Genotype Score (TGS)를 사용 하였다. TGS는 다음과 같은 절차를 이용하여 총 100점의 유전 자조합 점수를 만점으로 하여 유전자를 조합점수를 구한다.

(1) 각 다형성에 유전형 점수 (genotype score: GS)를 적용하 며, $A C E$ II 다형성에서 II는 2점, $I D$ 는 1점, $\mathrm{DD}$ 는 0점의 $\mathrm{GS}$ 를 부여한다. $A C T N 3 R 577 X$ 유전형에서 $R R$ 은 2점, $R X$ 는 1점, $\chi X$ 는 0 점의 $\mathrm{GS}$ 를 부여한다.

(2) 두 유전자의 $\mathrm{GS}$ 를 합한다. 즉, $\mathrm{GS}_{\mathrm{ACE}}+\mathrm{GS}_{\mathrm{ACNN} 3}$

(3) 합산된 GS를 다음의 식으로 환산하여 점수 범위가 0-100 점이 되도록 한다. 이때 얻어진 점수는 TGS (Total Genotype Score)로서 유전자조합한 점수로 해석한다.

$\mathrm{TGS}=(100 / 2) \times\left(\mathrm{GS}_{\mathrm{ACE}}+\mathrm{GS}_{\mathrm{ACTN} 3}\right)$

\section{자료처리 방법}

이 연구에서 얻은 자료는 $A C E$ 와 $A C T N 3$ 유전형 분포를 빈 도와 비율로 구하였다. 교차분석 $\left(\mathrm{x}^{2}\right)$ 을 이용하여 하디-웨인버 그 평형성을 검증하고 집단 간 분포의 차이를 검증하였다. 교 차분석에 의해 집단간 유전형분포에 차이가 나타나면, 두 집 단간 이산자료에 대한 모비율 검증과 Bonfferoni correction을 실시하였다. 교차분석시 사례수가 5 명 이하인 구역이 나올 경 우, Fisher의 정확성 검증을 실시하였다. 다중유전형 분석을 위해 유전자조합으로 얻어진 TGS는 집단별 기술통계량을 얻 은 후, 집단 간 차이검증을 일원변량분석(ANOVA) 후 Scheffe 사후검증을 하였다. 또한 유전형에 대한 승산비(Odds Ratio) 는 로짓선형모형 방법으로 검증하였다. 차이검증에 대한 유의 수준은 $p<0.05$ (일방향검증)이며, 모든 분석을 위해 SPSS 13.0 통계팩키지를 사용하였다.

\section{결 과}

\section{$\mathrm{ACE}$ 다형성 분포와 근파워성 경기력간의 관계}

한국인에서 근력운동 경기력에 따른 $A C E I D$ 다형성의 분 포를 비교하기 위해, 대조군(Control)과 근력종목 엘리트선수
(Elite-Class), 근력종목 국가대표선수(Top-Class)를 동원하였 다. 동원된 집단은 모두 하디-웨인버그 평형을 이루었다 (대조

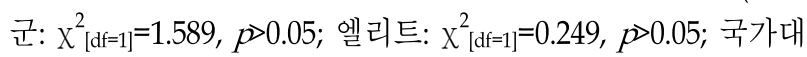
표: $\left.x_{[d \mathrm{~d}=1]}^{2}=2.963, p>0.05\right)$. 동원된 집단을 경기력 수준별로 $A C E$ 다형성의 분포를 분석한 결과는 Table 1 과 같다. 경기력 의 증가는 $I$ allele 및 $I I$ 유전형의 분포가 증가하는 경향을 가졌 고, $D$ allele 및 $D D$ genotype은 감소하는 경향을 가졌다 ( $p$ for trend <0.01). 이때 국가대표만이 대조군에 대한 유전자분포와 대립형 질분포에 차이를 가졌다 (Control vs. Top-Class: $p \times 0.05$ for allele, $p<0.05$ for genotype distribution). 따라서, $A C E I D$ 다형성은 최극단 수준의 근력 경기력에 대하여 관계하였다.

\section{ACTN3 R577X 다형성 분포와 근파워성 경기력간의 관계}

한국인에서 근력운동 경기력에 따른 ACTN3 R577X 다형성 분포를 위해 동원된 세집단의 유전자 및 대립형질분포는 Table 2와 같았다. 세 집단은 모두 하디-웨인버그 평형을 이루 었다(Control: $\quad x_{[d d=1]}^{2}=1.203, \quad p>0.05 ; \quad$ Elite: $x_{[d d=1]}^{2}=0.133$, $p>0.05$; Top-Level: $\left.x_{[d f=1]}^{2}=0.022, p>0.05\right)$. 경기력과 유전자분 포는 최상의 경기력에 도달할 때 $R$ allele과 $R R$ 유전형의 분포 가 증가하고 $X$ allele과 $X X$ 유전형이 감소하는 경향을 가졌다. 이에 따라 대조군 유전자 분포 및 대립형질 분포에 대하여 국가대표만이 유의한 차이를 나타냈다(Control vs. Top-Class: $p<0.05$ for allele, $p<0.05$ for genotype distribution). 따라서 $A C T N 3$ R577X 다형성도 역시 최극단 수준의 근력 경기력에 대하여 관계하였다.

\section{$\mathrm{ACE}-\mathrm{ACTN} 3$ 디중유전자 분포와 근파워성 경기력간의 관계}

한국인에서 $A C E I D$ 다형성과 $A C T N 3$ R577X 다형성이 각 각 근력 경기력과 관계성을 Table 1과 Table 2와 같이 확인을 하고, 두 유전자 다형성이 조합되어 근력 경기력과 관계를 분 석하였다. $A C E$ 와 $A C T N 3$ 유전자 다형성을 조합하였고, 이에 따른 근력 경기력 수준과 관계는 Table 3 과 같았다. 분석결과 $A C E$ 와 $A C T N 3$ 조합된 유전형의 분포는 경기력 증가와 함께 변화하는 경향이 유의하게 나타났다( $p$ for trend $<0.01)$. 이 때 대조군의 조합된 유전자 분포에 대하여 국가대표에서 우성조 합유전형 $(I I / I D+R R / R X)$ 은 유의하게 높은 분포를 가졌고, 열 성형 $(D D$ 유전형 또는 $X X$ 유전형)이 포함된 열성조합유전형 $(I I / I D+X X, D D+R R / R X, D D+X X)$ 은 모두 유의하게 감소된 분포를 가졌다(Control vs. Top-Class: $p \times 0.05)$. 따라서, $A C E$ 와 $A C T N 3$ 유전자는 조합되어 근력에 관계하며, 최극단 수준의 근력 경기력은 우성조합유전형을 선호하여 분포하였고, 열성 조합유전형을 회피하는 분포를 가졌다. ACE와 ACTN3 유전 자가 조합되어 근력과 관계하는 가를 확인하고 이를 해석하기 위한 또 다른 분석법으로 TGS를 구하였다. 경기력 수준별 집 단에 대한 TGS의 수준은 Fig. 1 과 같다. 두 유전자 $A C E$ 와 $A C T N 3$ 가 조합된 TGS는 근력 경기력 수준이 증가와 함께 유 
Table 1. $A C E$ genotype and allele frequencies in Korean power-oriented athletes

\begin{tabular}{|c|c|c|c|c|c|}
\hline \multirow{2}{*}{ Group (n) } & \multicolumn{3}{|c|}{ Genotype } & \multicolumn{2}{|c|}{ Allele } \\
\hline & II & $I D$ & $D D$ & $I$ & $D$ \\
\hline \multicolumn{6}{|l|}{ Total } \\
\hline Control $(n=676)$ & $\begin{array}{c}217 \\
(32.1)\end{array}$ & $\begin{array}{c}346 \\
(51.2)\end{array}$ & $\begin{array}{c}113 \\
(16.7)\end{array}$ & $\begin{array}{c}780 \\
(57.7)\end{array}$ & $\begin{array}{c}572 \\
(42.3)\end{array}$ \\
\hline Elite-Level $(n=158)$ & $\begin{array}{c}58 \\
(37.9)\end{array}$ & $\begin{array}{c}70 \\
(45.8)\end{array}$ & $\begin{array}{c}25 \\
(16.3)\end{array}$ & $\begin{array}{c}186 \\
(60.8)\end{array}$ & $\begin{array}{c}120 \\
(39.2)\end{array}$ \\
\hline Top-Level $(n=106)$ & $\begin{array}{c}46^{*^{*}} \\
(41.4)\end{array}$ & $\begin{array}{c}57 \\
(51.4)\end{array}$ & $\begin{array}{c}8 \\
(7.2)\end{array}$ & $\begin{array}{c}149^{*} \\
(67.1)\end{array}$ & $\begin{array}{c}73 \\
(32.9)\end{array}$ \\
\hline \multicolumn{6}{|l|}{ Male } \\
\hline Control $(n=358)$ & $\begin{array}{c}111 \\
(32.1)\end{array}$ & $\begin{array}{c}186 \\
(52.0)\end{array}$ & $\begin{array}{c}57 \\
(15.9)\end{array}$ & $\begin{array}{c}408 \\
(57.6)\end{array}$ & $\begin{array}{c}300 \\
(42.4)\end{array}$ \\
\hline Elite-Level $(\mathrm{n}=104)$ & $\begin{array}{c}37 \\
(35.6)\end{array}$ & $\begin{array}{c}47 \\
(45.2)\end{array}$ & $\begin{array}{c}20 \\
(19.2)\end{array}$ & $\begin{array}{c}121 \\
(58.2)\end{array}$ & $\begin{array}{c}87 \\
(41.8)\end{array}$ \\
\hline Top-Level $(n=70)$ & $\begin{array}{c}29^{*} \\
(41.4)\end{array}$ & $\begin{array}{c}37 \\
(52.9)\end{array}$ & $\begin{array}{c}4 \\
(5.7)\end{array}$ & $\begin{array}{c}95^{*} \\
(69.9)\end{array}$ & $\begin{array}{c}41 \\
(30.1)\end{array}$ \\
\hline \multicolumn{6}{|l|}{ Female } \\
\hline Control $(n=318)$ & $\begin{array}{c}102 \\
(32.1)\end{array}$ & $\begin{array}{c}160 \\
(50.3)\end{array}$ & $\begin{array}{c}56 \\
(17.6)\end{array}$ & $\begin{array}{c}364 \\
(57.2)\end{array}$ & $\begin{array}{c}272 \\
(42.8)\end{array}$ \\
\hline Elite-Level $(n=49)$ & $\begin{array}{c}21 \\
(42.9)\end{array}$ & $\begin{array}{c}23 \\
(46.9)\end{array}$ & $\begin{array}{c}5 \\
(10.2)\end{array}$ & $\begin{array}{c}65 \\
(66.3)\end{array}$ & $\begin{array}{c}33 \\
(33.7)\end{array}$ \\
\hline Top-Level $(n=41)$ & $\begin{array}{c}17 \\
(41.5)\end{array}$ & $\begin{array}{c}20 \\
(48.8)\end{array}$ & $\begin{array}{c}4 \\
(9.8) \\
\end{array}$ & $\begin{array}{c}54 \\
(65.9)\end{array}$ & $\begin{array}{c}28 \\
(34.1) \\
\end{array}$ \\
\hline
\end{tabular}

Values are number (percentage) within each group; ${ }^{a} p$ for trend in genotype $=0.006$, ${ }^{a} p$ for trend in allele $=0.008$, *significantly different from the control group at $p<0.05 ;{ }^{b} p$ for trend in genotype of male $=0.032,{ }^{b} p$ for trend in allele of male $=0.011$; ${ }^{c} p$ for trend in genotype of female $=0.025,{ }^{c} p$ for trend in allele of female $=0.027$.

Table 2. ACTN3 genotype and allele frequencies in Korean power-oriented athletes

\begin{tabular}{|c|c|c|c|c|c|}
\hline \multirow{2}{*}{ Group (n) } & \multicolumn{3}{|c|}{ Genotype } & \multicolumn{2}{|c|}{ Allele } \\
\hline & $R R$ & $R X$ & $X X$ & $R$ & $X$ \\
\hline \multicolumn{6}{|l|}{ Total } \\
\hline Control $(n=676)$ & $\begin{array}{c}196 \\
(29.0)\end{array}$ & $\begin{array}{c}349 \\
(51.6)\end{array}$ & $\begin{array}{c}131 \\
(19.4)\end{array}$ & $\begin{array}{c}741 \\
(54.8)\end{array}$ & $\begin{array}{c}611 \\
(45.2)\end{array}$ \\
\hline Elite-Level (n=158) & $\begin{array}{c}45 \\
(29.4)\end{array}$ & $\begin{array}{c}78 \\
(51.0)\end{array}$ & $\begin{array}{c}30 \\
(19.6)\end{array}$ & $\begin{array}{c}168 \\
(54.9)\end{array}$ & $\begin{array}{c}138 \\
(45.1)\end{array}$ \\
\hline Top-Level (n=106) & $\begin{array}{c}47^{*} \\
(42.3)\end{array}$ & $\begin{array}{c}51 \\
(45.9)\end{array}$ & $\begin{array}{c}13 \\
(11.7)\end{array}$ & $\begin{array}{c}145^{*} \\
(65.3)\end{array}$ & $\begin{array}{c}77 \\
(34.7)\end{array}$ \\
\hline \multicolumn{6}{|l|}{ Male } \\
\hline Control $(n=358)$ & $\begin{array}{c}91 \\
(25.4)\end{array}$ & $\begin{array}{c}192 \\
(53.6)\end{array}$ & $\begin{array}{c}75 \\
(20.9)\end{array}$ & $\begin{array}{c}374 \\
(52.2)\end{array}$ & $\begin{array}{c}342 \\
(47.8)\end{array}$ \\
\hline Elite-Level (n=104) & $\begin{array}{c}33 \\
(31.7)\end{array}$ & $\begin{array}{c}51 \\
(49.0)\end{array}$ & $\begin{array}{c}20 \\
(19.2)\end{array}$ & $\begin{array}{c}117 \\
(56.3)\end{array}$ & $\begin{array}{c}91 \\
(43.8)\end{array}$ \\
\hline Top-Level $(\mathrm{n}=70)$ & $\begin{array}{c}28^{* \prime} \\
(40.0)\end{array}$ & $\begin{array}{c}34 \\
(48.6)\end{array}$ & $\begin{array}{c}8 \\
(11.4)\end{array}$ & $\begin{array}{c}90^{*} \\
(64.3)\end{array}$ & $\begin{array}{c}50 \\
(35.7)\end{array}$ \\
\hline \multicolumn{6}{|l|}{ Female } \\
\hline Control $(n=318)$ & $\begin{array}{c}105 \\
(33.0)\end{array}$ & $\begin{array}{c}157 \\
(49.4)\end{array}$ & $\begin{array}{c}56 \\
(17.6)\end{array}$ & $\begin{array}{c}367 \\
(57.7)\end{array}$ & $\begin{array}{c}269 \\
(42.3)\end{array}$ \\
\hline Elite-Level $(\mathrm{n}=49)$ & $\begin{array}{c}12 \\
(24.5)\end{array}$ & $\begin{array}{c}27 \\
(55.1)\end{array}$ & $\begin{array}{c}10 \\
(20.4)\end{array}$ & $\begin{array}{c}51 \\
(52.0)\end{array}$ & $\begin{array}{c}47 \\
(48.0)\end{array}$ \\
\hline Top-Level $(n=41)$ & $\begin{array}{c}19 \\
(46.3)\end{array}$ & $\begin{array}{c}17 \\
(41.5)\end{array}$ & $\begin{array}{c}5 \\
(12.2)\end{array}$ & $\begin{array}{c}55 \\
(67.1)\end{array}$ & $\begin{array}{c}27 \\
(32.9)\end{array}$ \\
\hline
\end{tabular}

Values are number (percentage) within each group, $p$ for trend in genotype $=0.010, p$ for trend in allele $=0.012$, *significantly different from the control group at $p<0.05$; ${ }^{6} p$ for trend in genotype of male $=0.007,{ }^{b} p$ for trend in allele of male $=0.005$; ${ }^{c} p$ for trend in genotype of female $=0.172,{ }^{c} p$ for trend in allele of female $=0.173$. 
Table 3. polygenic distribution of $A C E$ and $A C T N 3$ in Korean power-oriented athletes

\begin{tabular}{|c|c|c|c|c|}
\hline \multirow{3}{*}{ Group (n) } & \multicolumn{4}{|c|}{ Genotype } \\
\hline & \multicolumn{2}{|c|}{$I H+I D$} & \multicolumn{2}{|c|}{$D D$} \\
\hline & $R R+R X$ & $X X$ & $R R+R X$ & $X X$ \\
\hline \multicolumn{5}{|l|}{ Total } \\
\hline Control $(n=676)$ & $\begin{array}{c}451 \\
(66.7)\end{array}$ & $\begin{array}{c}112 \\
(16.6)\end{array}$ & $\begin{array}{c}94 \\
(13.9)\end{array}$ & $\begin{array}{c}19 \\
(2.8)\end{array}$ \\
\hline Elite-Level $(n=158)$ & $\begin{array}{c}102 \\
(66.7)\end{array}$ & $\begin{array}{c}26 \\
(17.0)\end{array}$ & $\begin{array}{c}21 \\
(13.7)\end{array}$ & $\begin{array}{c}4 \\
(2.6)\end{array}$ \\
\hline Top-Level $(n=106)$ & $\begin{array}{c}92^{*^{\prime}} \\
(82.9)\end{array}$ & $\begin{array}{c}11 \\
(9.9)\end{array}$ & $\begin{array}{c}6 \\
(5.4)\end{array}$ & $\begin{array}{c}2 \\
(1.8)\end{array}$ \\
\hline \multicolumn{5}{|l|}{ Male } \\
\hline Control $(n=358)$ & $\begin{array}{c}235 \\
(65.6)\end{array}$ & $\begin{array}{c}66 \\
(18.4)\end{array}$ & $\begin{array}{c}48 \\
(13.4)\end{array}$ & $\begin{array}{c}9 \\
(2.5)\end{array}$ \\
\hline Elite-Level $(n=104)$ & $\begin{array}{c}68 \\
(65.4)\end{array}$ & $\begin{array}{c}16 \\
(15.4)\end{array}$ & $\begin{array}{c}16 \\
(15.4)\end{array}$ & $\begin{array}{c}4 \\
(3.8)\end{array}$ \\
\hline Top-Level $(\mathrm{n}=70)$ & $\begin{array}{c}59^{*} \\
(84.3)\end{array}$ & $\begin{array}{c}7 \\
(10.0)\end{array}$ & $\begin{array}{c}3 \\
(4.3)\end{array}$ & $\begin{array}{c}1 \\
(1.4)\end{array}$ \\
\hline \multicolumn{5}{|l|}{ Female } \\
\hline Control $(n=318)$ & $\begin{array}{c}216 \\
(67.9)\end{array}$ & $\begin{array}{c}46 \\
(14.5)\end{array}$ & $\begin{array}{c}46 \\
(14.5)\end{array}$ & $\begin{array}{c}10 \\
(3.1)\end{array}$ \\
\hline Elite-Level $(n=49)$ & $\begin{array}{c}34 \\
(69.4)\end{array}$ & $\begin{array}{c}10 \\
(20.4)\end{array}$ & $\begin{array}{c}5 \\
(10.2)\end{array}$ & $\begin{array}{c}0 \\
(0.0)\end{array}$ \\
\hline Top-Level $(n=41)$ & $\begin{array}{c}33 \\
(80.5)\end{array}$ & $\begin{array}{c}4 \\
(9.8)\end{array}$ & $\begin{array}{c}3 \\
(7.3)\end{array}$ & $\begin{array}{c}1 \\
(2.4)\end{array}$ \\
\hline
\end{tabular}

Values are number (percentage) within each group, $p$ for trend $=0.006$, *significantly different from the control group at $p<0.05$; ${ }^{\mathrm{b}} p$ for trend in genotype of male $=0.027$; ${ }^{\mathrm{c}} p$ for trend in genotype of female $=0.043$.

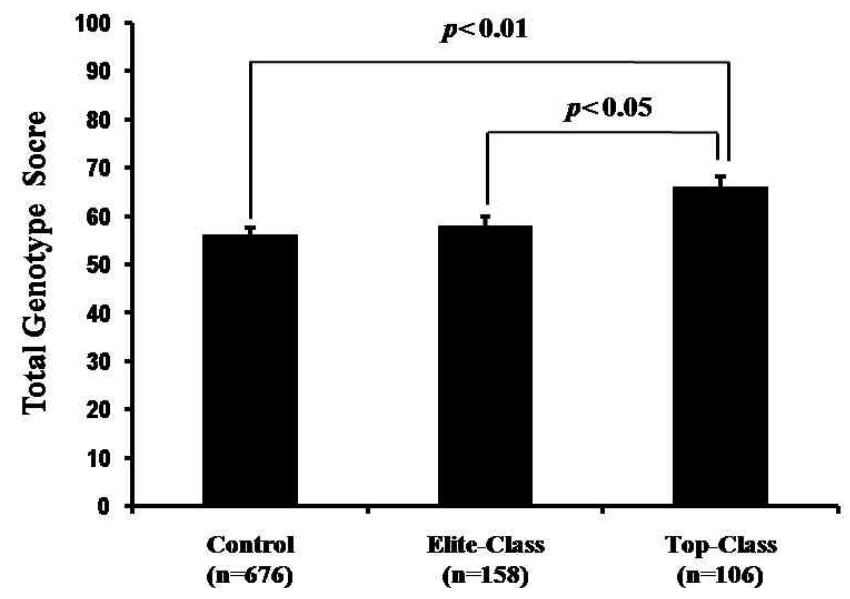

Fig. 1. Total Genotype Score in top- and elite-class power performance.

의하게 증가하여 국가대표의 TGS가 대조군과 엘리트보다 유 의하게 높았다(Top-Level vs. Control=66 \pm 2.3 vs. $56 \pm 0.9$, $p<0.01$; Top-Level vs. Elite-Level=66 \pm 2.3 vs. $58 \pm 1.9 ; p<0.05)$. $A C E$ 와 $A C T N 3$ 가 상호 조합하여 근력의 경기력과 관련된 것 이 확인되어, 최종적으로 조합된 유전자형 중 우성조합유전형 이 열성조합유정형에 대하여 최우수 근력 경기력을 가질 가능 성을 승산비로 구하였다(Table 4). 분석결과에서 우성조합유
전형은 열성조합유전형에 대하여 대표선수 경기력을 가질 가 능성이 2.43 배( $95 \% \mathrm{CI}: 1.45 \sim 4.09, p<0.01)$ 의 수준으로 유의하게 높았다.

\section{고 찰}

이 연구는 한국인에게 적용할 수 있는 근력관련 유전적 정 보를 $A C E$ 유전자와 $A C T N 3$ 유전자를 단일유전자적 수준과 다중유전자적 수준에서 접근하여 이해하고자 목적하였다. 이 를 위해 근력을 대표할 수 있는 종목의 집단을 경기력 수준에 따라 구분하여 $A C E$ 다형성 분포와 $A C T N 3$ 다형성분포를 단 일 및 다중유전자 수준에서 비교하였다. 단일유전자 수준에서 $A C E$ 다형성과 $A C T N 3$ 다형성은 각각 최극단의 경기력 수준 에서 유전자 분포의 차이가 나타났다. 이 결과로 $A C E$ 다형성 과 $A C T N 3$ 다형성이 각각 한국인에서 근력과 관련된 유전자 인 것이 확인되었다. 이를 바탕으로 $A C E$ 다형성과 $A C T N 3$ 다형성을 조합한 유전형의 분포를 다중유전자 차원에서 근력 에 따른 경기력 수준과 비교하고, TGS를 이용하여 경기력별로 비교하고, 마지막으로 승산비로 분석한 결과, 두 유전자가 상 호조합된 다중유전자형에서 경기력에 따른 유전분포가 나타 났다. 이는 $A C E$ 다형성과 $A C T N 3$ 다형성이 상호작용하여 협 력적인 관계에서 근력의 유전자적 수준을 결정할 것으로 제안 
Table 4. Odds ratios in polygenic distribution of $A C E$ and $A C T N 3$ of power performance

\begin{tabular}{ccc}
\hline & $I I / I D+R R / R X$ & Others $^{\dagger}$ \\
\hline Elite-Level & 1.123 & 1 (Reference) \\
Top-Level & $(95 \% \mathrm{CI}: 0.837 \sim 1.506 ; p=0.439)$ & 1 (Reference) \\
\hline
\end{tabular}

$\dagger=$ Others are composed of $D D+R R / R X, D D+X X$, and $R R / R X+D D$ in the hybrid genotype.

된다. 한편, $A C E$ 다형성과 $A C T N 3$ 다형성이 단일 유전자 수준 과 다중유전자 수준에서 모두 최극단의 경기력에서만 유의한 유전자분포의 차이를 나타내어, 일반인 수준에서는 $A C E$ 다형 성과 $A C T N 3$ 다형성에 의한 근력의 영향력이 발견되기 어려 울 것으로 제안되며, 극단의 근력 수준으로 표현되는 경우에 $A C E$ 와 $A C T N 3$ 다형성이 영향을 미칠 것으로 사료된다.

이 연구에서 $A C E I D$ 다형성은 최극단의 근력 경기력에서 $I I$ 유전형 및 $I$ 대립형질이 증가하고 $D D$ 유전형 및 $D$ 대립형질 이 감소하였다. 이는 $A C E I D$ 다형성이 근력발달에 유의한 유 전형으로 제안될 수 있다. $A C E I D$ 다형성이 근력관련 유전자 로 가능성이 있는 것은 레닌-앤지오텐신계(RAS)의 최종물질 인 앤지오텐신의 작용에 조절에 근거할 수 있다. 안지오텐신 전환효소(ACE)의 기능은 비활성형인 앤지오텐신 I 을 활성형 인 앤지오텐신프로 전환시키며, 안지오텐신전환효소(ACE) 활성수준에 따라 비례적으로 앤지오텐신 I 에서 앤지오텐신 II로 전환된다. 이때 높은 $\mathrm{ACE}$ 활성도에 의해 증가된 앤지오 텐신 $\Pi$ 는 혈관계의 혈관을 수축시켜 체순환계와 말초순환계 혈압을 높이고 심장의 심실후부하(afterload)를 증가시켜 심박 출을 위한 좌심실의 일량을 증가시키며, 이로 인해 좌실의 심 근수축이 더욱 강하게 수축하도록 부담을 주게 된다. 또한 수 축된 말초혈관계는 혈류의 공급을 줄이는 결과는 가져오는데, 감소된 혈류의 공급은 산소와 영양소공급 및 노폐물제거 속도 가 감소하게 된다[13]. 이러한 기전은 근력 운동 후 회복기에 운동한 근육으로 충분한 혈류가 공급되지 못해 운동에 의해 생성된 피로물질 및 노폐물의 제거와 함께 산소와 영양소 공 급이 지연되어 근육의 회복과 성장 및 발달에 어려움을 초래 할 수 있다[9,19]. 또한 증가된 앤지오텐신II는 심장의 심근세 포와 혈관의 평활근세포에서 성장인자로 작용하여 혈관벽 두 께를 증가시키고 구심성 심실비대를 촉진시켜 혈액순환이 감 소된다 $[7,13,18]$. 반면, 심근세포와 평활근세포의 작용과 다르 게 앤지오텐신 $\Pi$ 증가는 골격근의 근세포에서 단백질 분해 기전을 활성화시켜, 근육의 근위축 특히 속근을 감소시키며, 근력과 근수축력을 감소시키는 것으로 밝혀졌다. 즉, $\mathrm{ACE}$ 의 높은 활성도에 의해 증가된 앤지오텐신 ㅍㄴ는 심근세포와 평활 근세포에서는 성장인자로, 근육세포에서는 분해인자로 작용 하는 조직특이적인 작용을 하며, 이로 인해 구심성 좌심실 비 대와 혈관 강축을 일으키는 반면, 근위축을 유발하고 근기능 을 감소시킨다[2,315,24,36,37,40]. 높은 활성도를 가진 $D D$ 유
전형은 심근과 혈관의 비대, 근육의 위축을 가속화하여 무산 소근파워 발달을 지연할 수 있으며, 반면 $I I$ 유전형은 근비대 및 속근의 성장과 발달에 효과적으로 작용하여 성장과 발달에 효과적으로 작용하여 최대 근력을 향상시킬수 있을 것이다.

한편 ACTN3 R577X 다형성에서 한국인의 근력에 대한 경 기력 수준이 최극단일 때, $R R$ 유전형 및 $R$ 대립형질의 분포는 크게 증가하지만, $X X$ 유전형 및 $X$ 대립형질은 감소하였다. 위의 결과는 Yang 등[48]과 Papadimitriou 등[26]이 보고한 연구결과와 일치하는 것으로 근력운동 종목의 대표급선수는 높은 $R$ 대립형질과 $R R$ 유전형 분포를 보고했고, 이 결과로 $A C T N 3$ 는 최대 근수축력에 영향을 미치며 근력 운동종목에 주요한 유전자로 판단된다. $A C T N 3$ 가 최대 근력관련 유전자 인 것은 $A C T N 3$ 유전자가 발현하는 단백질인 a-actinin-3의 해부학적·생리학적·생화학적 기전에서 설명된다. a-actinin-3 는 강한 근수축에 동원되는 속근에서만 조직특이적으로 발현 하여, 근수축의 근원적 단위인 근절(sarcomere)을 형성하는 Z-line을 형성한다. 속근내 Z-line의 a-actinin-3는 수축 근세사 (myofilament)인 액틴과 교차결합(crossover binding)을 하여 공간적으로 안정성을 확보하고, 액틴을 단단히 지지한다. 이 와 함께 마이오신 다발의 중심에 위치한 티틴(titin)과도 교차 결합을 하고 있어 마이오신의 구조적 공간을 안정시키고 근수 축을 지지한다. 더욱이 a-actinin-3는 당대사효소인 fructose-1,6-bis-phosphatase, glycogen phosphorylase amorphin 와 근섬유 분화 인자인 calsarcins와 결합하여 속근 섬유 분화 과정과 에너지 대사를 조절하는 기전을 가지고 있다 [20,22,48,49]. a-Actinin-3는 속근에서만 발현(fast fiber muscle-specific expression)하여 속근의 강한 근수축에 대한 안정 적 구조형성과 지지기능을 역할하며 에너지대사 및 조직의 분화과정을 조절한다. 구조, 대사, 및 발생에 대한 조절기능을 통해 $A C T N 3$ 는 속근이 보다 특성화된 기능을 갖도데 기여하 고 있다. 즉, 속근의 가장 중요한 특성인 강한 수축력에 대한 최대 근력을 조절한다. 이같은 기전으로 속근에서 a-actinin-3 가 발현되는 $R R$ 유전형은 근력의 발달과 최대수준의 경기력 에 긍정적으로 관여할 것이며, 속근에서는 a-actinin-2가 보상 적으로 발현되는 것이다.

이 연구에서 $A C E I D$ 다형성과 $A C T N 3$ 다형성은 각각 근력 종목의 경기력에 선호되는 유전자로 확인되었다. 그러나 근력 은 다차원적인 요인에 의해 결정이 되며 근력의 유전적 요인 
또한 다중유전자에 의해 결정이 된다. 따라서 단일 유전적 요 인에서 확인된 유전자를 조합하여 다중유전적 요인에서 근력 에 대한 관계를 설명하고자 하였다. 두 유전자 $(A C E \& A C T N 3)$ 를 조합하여 근력 경기력 수준에 대한 관계를 분석한 결과, 최우수 근력 경기력에서 우성조합유전형(II/ID+RR/RX)이 높은 분포를 가지고, $D D$ 혹은 $X X$ 가 조합된 열성조합유전형 $(D D+R R / R X$ or $D D+X X$ or $I I / I D+X X)$ 의 분포는 감소하였 다. 또한 두 유전형을 점수화하여 TGS를 구하고 비교한 결과, 최우수 근력 경기력은 우성조합유전형으로 조합된 TGS를 가 질 수록 높은 경기력을 나타내었다. 이 결과는 근력에 $A C E$ 와 $A C T N 3$ 가 서로 협력적으로 작용하여 선호되는 유전형의 조합 으로 근력에 관계하는 것을 의미하였다. 다중유전자 수준에서 근력에 대한 관계를 보고한 연구는 한국인을 대상으로 찾아볼 수 없었으나, 최근 지구성 경기력과 관련한 다중유전자의 효 과는 서양인을 대상으로 몇 몇 연구자에 의해서 보고되었다 $[11,39,44,46]$. 이들 연구자들의 보고에서도 지구성 경기력에서 다중유전형으로 조합되었을 때 지구성 경기력의 설명력이 높 았으며 지구성이 다중유전자의 조합에 의해 형성이 될 것으로 주장되었다. 선행연구와 이 연구에서 확인된 결과로 근력에 대한 유전적인 설명을 위해서 단일유전자의 수준과 함께 다중 유전자의 수준에서 해석이 필요한 것으로 나타났으며, 본 연 구에서 승산비를 구한 결과 $A C E$ 와 $A C T N 3$ 유전형의 $I I / I D+R R / R X$ 의 우성유전조합형이 최우수 근력의 경기력을 가진 가능성이 나머지 유전조합형에 비하여 2.4 배 수준으로 높은 가능성을 가졌다. 따라서 근력종목에서 경기력의 수준을 $A C E$ 와 $A C T N 3$ 유전자를 조합하여 근력종목에서 경기력의 수 준을 예측할 수 있을 것으로 사료된다.

한편, 이 연구에서 단일유전자 수준과 다중유전자 수준에서 근력의 경기력 수준에 대한 차이를 분석하였을 때, 항상 근력 종목 국가대표에서만 유의하게 유전자 분포의 차이가 나타났 다. 이는 $A C E$ 와 $A C T N 3$ 유전자는 최극단치의 잠재적인 근력 수준을 결정할 것으로 사료된다. 그리고 이 사실을 근거할 때, 최극단치까지 도달하지 않는 근력은 $A C E$ 유전자와 $A C T N 3$ 유전자에 대한 관계가 발견되기 어려울 것이다. 실제로 선행 된 많은 연구에서 성장기 청소년의 근력이나 성인에서 저항성 훈련에 따른 근력이 $A C E$ 나 $A C T N 3$ 유전형에 따라 차이가 나 타나지 않는 것으로 보고하였다[32,35,38]. 이들 선행연구에서 근력의 수준과 훈련에 의해 향상된 근력의 수준이 잠재적으로 가지고 있는 최극단의 근력까지 유발하지 않기 때문에 $A C E$ 및 $A C T N 3$ 유전형에 따른 차이가 발견되지 않을 것으로 사료 된다. 향후 $A C E$ 와 $A C T N 3$ 가 근력에 미치는 유전적 영향력을 밝히기 위해서는 최극단의 근력수준이 표현되는 집단이 타당 할 것으로 사료된다.

\section{감사의 글}

이 논문은 2011년도 정부재원(교육과학기술부)으로 한국연
구재단의 지원을 받아 연구되었음[NRF-2011-358-G00025]. 이 에 한국연구재단의 연구지원에 감사드립니다.

\section{References}

1. Bouchard, C., Malina, R. and Pérusse, L. 1997. Genetics of Fitness and Physical Performance Human Kinetics, Champaign, Illinois.

2. Brink, M., Price, S. R., Chrast, J., Bailey, J. L., Anwar, A., Mitch, W. E. and Delafontaine, P. 2001. Angiotensin II induces skeletal muscle wasting through enhanced protein degradation and down-regulates autocrine insulin-like growth factor I. Endocrinology 142, 1489-1496.

3. Brink, M., Wellen, J. and Delafontaine, P. 1996. Angiotensin II causes weight loss and decreases circulating insulin-like growth factor $\mathrm{I}$ in rats through a pressor-independent mechanism. J. Clin. Invest. 97, 2509-2516.

4. Cohn, R. D., van Erp, C., Habashi, J. P., Soleimani, A. A., Klein, E. C., Lisi, M. T., Gamradt, M., ap Rhys, C.M., Holm, T. M., Loeys, B. L., Ramirez, F., Judge, D. P., Ward, C. W. and Dietz, H. C. 2007. Angiotensin II type 1 receptor blockade attenuates TGF-beta-induced failure of muscle regeneration in multiple myopathic states. Nat. Med 13, 204-210.

5. Delmonico, M. J., Kostek, M. C., Doldo, N. A., Hand, B. D., Walsh, S., Conway, J. M., Carignan, C. R., Roth, S. M. and Hurley, B. F. 2007. Alpha-actinin-3 (ACTN3) R577X polymorphism influences knee extensor peak power response to strength training in older men and women. $J$. Gerontol. A Biol. Sci. Med Sci. 62, 206-212.

6. Druzhevskaya, A. M., Ahmetov, I. I., Astratenkova, I. V. and Rogozkin. V. A. 2008. Association of the ACTN3 R577X polymorphism with power athlete status in Russians. Eur. J. Appl. Physiol. 103, 631-634.

7. Dzau, V. J., Gibbons, G. H. and Pratt, R. E. 1991. Molecular mechanisms of vascular renin-angiotensin system in myointimal hyperplasia. Hypertension 18, II100-105.

8. Eynon, N., Alves, A. J., Meckel, Y., Yamin, C., Ayalon, M., Sagiv, M. and Sagiv, M. 2010. Is the interaction between HIF1A P582S and ACTN3 R577X determinant for power/sprint performance? Metabolism 59, 861-865.

9. Fagard, R. H. 1997. Impact of different sports and training on cardiac structure and function. Cardiol. Clin. 15, 397-412.

10. Frey, N., Richardson, J. A. and Olson, E. N. 2000. Calsarcins, a novel family of sarcomeric calcineurin-binding proteins. Proc. Natl. Acad Sci. USA 97, 14632-14637.

11. Gomez-Gallego, F., Santiago, C., Gonzalez-Freire, M., Muniesa, C. A., Fernandez Del Valle, M., Perez, M., Foster, C. and Lucia, A. 2009. Endurance performance: genes or gene combinations? Int. J. Sports Med 30, 66-72.

12. Hagberg, J. M., Rankinen, T., Loos, R. J., Perusse, L., Roth, S. M., Wolfarth, B. and Bouchard, C. 2011. Advances in exercise, fitness, and performance genomics in 2010. Med Sci. Sports Exerc. 43, 743-752.

13. Henriksen, E. J. and Jacob, S. 2003. Modulation of metabolic 
control by angiotensin converting enzyme (ACE) inhibition. J. Cell Physiol. 196, 171-179.

14. Hughes, D. C., Day, S. H., Ahmetov, I. I. and Williams, A. G. 2011. Genetics of muscle strength and power: polygenic profile similarity limits skeletal muscle performance. $J$. Sports Sci. 29, 1425-1434.

15. Kasikcioglu, E., Kayserilioglu, A., Ciloglu, F., Akhan, H., Oflaz, H., Yildiz, S. and Peker, I. 2004. Angiotensin-converting enzyme gene polymorphism, left ventricular remodeling, and exercise capacity in strength-trained athletes. Heart Vessels 19, 287-293.

16. Kim, C. H., Cho, J. Y., Jeon, J. Y., Koh, Y. G., Kim, Y. M., Kim, H. J., Park, M., Um, H. S. and Kim, C. 2010. ACE DD genotype is unfavorable to Korean short-term muscle power athletes. Int. J. Sports Med 31, 65-71.

17. Koch, W., Latz, W., Eichinger, M., Ganser, C., Schomig, A. and Kastrati, A. 2005. Genotyping of the angiotensin I-converting enzyme gene insertion/deletion polymorphism by the TaqMan method. Cin. Chem 51, 1547-1549.

18. Koh, T. J. and Tidball, J. G. 1999. Nitric oxide synthase inhibitors reduce sarcomere addition in rat skeletal muscle. J. Physiol. 519 Pt 1, 189-196.

19. Longhurst, J. C. and Stebbins, C. L. 1997. The power athlete. Cardiol. Clin. 15, 413-429.

20. Macarthur, D. G. and North, K. N. 2005. Genes and human elite athletic performance. Hum Genet. 116, 331-339.

21. MacArthur, D. G. and North, K. N. 2004. A gene for speed? The evolution and function of alpha-actinin-3. Bioessays 26, 786-795.

22. MacArthur, D. G., Seto, J. T., Raftery, J. M., Quinlan, K. G., Huttley, G. A., Hook, J. W., Lemckert, F. A., Kee, A. J., Edwards, M. R., Berman, Y., Hardeman, E. C., Gunning, P. W., Easteal, S., Yang, N. and North, K. N. 2007. Loss of ACTN3 gene function alters mouse muscle metabolism and shows evidence of positive selection in humans. Nat. Genet. 39, 1261-1265.

23. Montgomery, H., Clarkson, P., Barnard, M., Bell, J., Brynes, A., Dollery, C., Hajnal, J., Hemingway, H., Mercer, D., Jarman, P., Marshall, R., Prasad, K., Rayson, M., Saeed, N., Talmud, P., Thomas, L., Jubb, M., World, M. and Humphries, S. 1999. Angiotensin-converting-enzyme gene insertion/deletion polymorphism and response to physical training. Lancet 353, 541-545.

24. Mori, S. and Tokuyama, K. 2007. Variation in ACE activity affects myogenic differentiation in $\mathrm{C} 2 \mathrm{C} 12$ cells. Biochem Biophys. Res. Commun. 353, 369-375.

25. North, K. N., Yang, N., Wattanasirichaigoon, D., Mills, M., Easteal, S. and Beggs, A. H. 1999. A common nonsense mutation results in alpha-actinin-3 deficiency in the general population. Nat. Genet. 21, 353-354.

26. Papadimitriou, I. D., Papadopoulos, C., Kouvatsi, A. and Triantaphyllidis, C. 2008. The ACTN3 gene in elite Greek track and field athletes. Int. J. Sports Med 29, 352-355.

27. Powers, S. K. and Dodd, S. L. 2009. Total Fitness and Wellness. Pearson Benjamin Cummings, San Francisco.

28. Puthucheary, Z., Skipworth, J. R., Rawal, J., Loosemore, M.,
Van Someren, K. and Montgomery, H. E. 2011. The ACE gene and human performance: 12 years on. Sports Med 41, 433-448.

29. Puthucheary, Z., Skipworth, J. R., Rawal, J., Loosemore, M., Van Someren, K. and Montgomery, H. E. 2011. Genetic influences in sport and physical performance. Sports Med 41, 845-859.

30. Rigat, B., Hubert, C., Alhenc-Gelas, F., Cambien, F., Corvol, P. and Soubrier, F. 1990. An insertion/deletion polymorphism in the angiotensin I-converting enzyme gene accounting for half the variance of serum enzyme levels. $J$. Cin. Invest. 86, 1343-1346.

31. Rigat, B., Hubert, C., Corvol, P. and Soubrier, F. 1992. PCR detection of the insertion/deletion polymorphism of the human angiotensin converting enzyme gene (DCP1) (dipeptidyl carboxypeptidase 1). Nucleic Acids Res. 20, 1433.

32. Rodriguez-Romo, G., Ruiz, J. R., Santiago, C., Fiuza-Luces, C., Gonzalez-Freire, M., Gomez-Gallego, F., Moran, M. and Lucia, A. 2010. Does the ACE I/D polymorphism, alone or in combination with the ACTN3 R577X polymorphism, influence muscle power phenotypes in young, non-athletic adults? Eur. J. Appl. Physiol. 110, 1099-1106.

33. Roth, S. M., Walsh, S., Liu, D., Metter, E. J., Ferrucci, L. and Hurley, B. F. 2008. The ACTN3 R577X nonsense allele is under-represented in elite-level strength athletes. Eur. J. Hum Genet. 16, 391-394.

34. Ruiz, J. R., Arteta, D., Buxens, A., Artieda, M., Gomez-Gallego, F., Santiago, C., Yvert, T., Moran, M. and Lucia, A. 2010. Can we identify a power-oriented polygenic profile? J. Appl. Physiol. 108, 561-566.

35. Ruiz, J. R., Fernandez del Valle, M., Verde, Z., Diez-Vega, I., Santiago, C., Yvert, T., Rodriguez-Romo, G., Gomez-Gallego, F., Molina, J. J. and Lucia, A. 2011. ACTN3 R577X polymorphism does not influence explosive leg muscle power in elite volleyball players. Scand J. Med Sci. Sports. 21, e34-41.

36. Russell, S. T., Sanders, P. M. and Tisdale, M .J. 2006. Angiotensin II directly inhibits protein synthesis in murine myotubes. Cancer Lett. 231, 290-294.

37. Sanders, P. M., Russell, S. T. and Tisdale, M. J. 2005. Angiotensin II directly induces muscle protein catabolism through the ubiquitin-proteasome proteolytic pathway and may play a role in cancer cachexia. Br. J. Cancer 93, 425-434.

38. Santiago, C., Rodriguez-Romo, G., Gomez-Gallego, F., Gonzalez-Freire, M., Yvert, T., Verde, Z., Naclerio, F., Altmae, S., Esteve-Lanao, J. R., Ruiz, J. and Lucia, A. 2010. Is there an association between ACTN3 R577X polymorphism and muscle power phenotypes in young, non-athletic adults? Scan. J. MedSci. Sports 20, 771-778.

39. Santiago, C., Ruiz, J. R., Muniesa, C. A., Gonzalez-Freire, M., Gomez-Gallego, F. and Lucia, A. 2010. Does the polygenic profile determine the potential for becoming a world-class athlete? Insights from the sport of rowing. Scand J. Med Sci. Sports 20, e188-94.

40. Song, Y. H., Li, Y., Du, J., Mitch, N. Rosenthal, and Delafontaine, P. 2005. Muscle-specific expression of IGF-1 
blocks angiotensin II-induced skeletal muscle wasting. J. Clin. Invest. 115, 451-458.

41. Soubrier, F., Wei, L., Hubert, C., Clauser, E., Alhenc-Gelas, F. and Corvol, P. 1993. Molecular biology of the angiotensin I converting enzyme: II. Structure-function. Gene polymorphism and clinical implications. J. Hypertens 11, 599-604.

42. Taniwaki, H., Ishimura, E., Matsumoto, N., Emoto, E., Inaba, M. and Nishizawa, Y. 2001. Relations between ACE gene and ecNOS gene polymorphisms and resistive index in type 2 diabetic patients with nephropathy. Diabetes Care 24, 1653-1660.

43. Thomis, M. A., Huygens, W., Heuninckx, S., Chagnon, M., Maes, H. H., Claessens, A. L., Vlietinck, R., Bouchard, C. and Beunen, G. P. 2004. Exploration of myostatin polymorphisms and the angiotensin-converting enzyme insertion/deletion genotype in responses of human muscle to strength training. Eur. J. Appl. Physiol. 92, 267-274.

44. Tsianos, G. I., Evangelou, E., Boot, A., Zillikens, M. C., van Meurs, J. B., Uitterlinden, A. G. and Ioannidis, J. P. 2010. Associations of polymorphisms of eight muscle- or metabolism-related genes with performance in Mount Olympus marathon runners. J. Appl. Physiol. 108, 567-574.

45. Walsh, S., Liu, D., Metter, E. J., Ferrucci, L. and Roth, S. M. 2008. ACTN3 genotype is associated with muscle phenotypes in women across the adult age span. J. Appl. Physiol. 105, 1486-1491.

46. Williams, A. G. and Folland, J. P. 2008. Similarity of polygenic profiles limits the potential for elite human physical performance. J. Physiol. 586, 113-121.

47. Yang, N., Garton, F. and North, K. 2009. Alpha-Actinin-3 and Performance. Med Sport. Sci. 54, 88-101.

48. Yang, N., MacArthur, D. G., Gulbin, J. P., Hahn, A. G., Beggs, A. H., Easteal, S. and North, K. 2003. ACTN3 genotype is associated with human elite athletic performance. Am J. Hum Genet. 73, 627-631.

49. Yang, N., Schindeler, A., McDonald, M. M., Seto, J. T., Houweling, P. J., Lek, M. Hogarth, M., Morse, A. R., Raftery, J. M. Balasuriya, D., MacArthur, D. G., Berman, Y., Quinlan, K. G., Eisman, J. A., Nguyen, T. V., Center, J. R., Prince, R. L., Wilson, S. G., Zhu, K., Little, D. G. and North, K. N. 2011. alpha-Actinin-3 deficiency is associated with reduced bone mass in human and mouse. Bone 49, 790-798.

\section{초록 : $A C E$ 와 $A C T N 3$ 의 다중유전형질과 근력운동 경기력간의 관계}

\section{김철현*}

(한국체육대학교 체육과학연구소)

이 연구는 한국인에서 적용할 수 있는 근력관련 유전적 소인을 $A C E$ 유전자와 $A C T N 3$ 유전자를 단일유전자 수준과 다중유전자 수준에서 관계성을 규명하는데 목적이 있다. 연구의 목적을 위해 근력운동종목의 엘리트선수 158 명, 국가대표선수 106 명, 대조군 676명을 동원하여 $A C E I D$ 다형성과 ACTN3 R577X 다형성 분포를 분석했다. 연구결과, $A C E$ 다형성에서 $I I$ 유전형 및 $I$ 대립형질은 유의하게 높은 분포를 가졌고, 반면 $D D$ 유전형 및 $I$ 대립형 질은 유의하게 낮은 분포를 가졌다(Top-Class vs. Control: $41.4 \%$ vs. 32.1 for II genotype, $67.1 \%$ vs. $57.7 \%$ for $I$ allele, $p<0.05)$. ACTN3 다형성에서 $R R$ 유전형 및 $R$ 대립형질은 유의하게 높았고 $X X$ 유전형 및 $R$ 대립형질은 유의하게 낮았다(Top-Class vs. Control: $42.3 \%$ vs. 29.0 for $R R$ genotype, $65.3 \%$ vs. $54.8 \%$ for $R$ allele, $p \times 0.05$ ). 다중유전자 수준에서 근력은 $A C E$ 다형성과 $A C T N 3$ 다형성이 조합된 우성조합유전형 $(I I I D+R R / R X)$ 이 최우수 경기력에서 유의하게 높은 분포를 가졌다(Top-Class vs. Control: $82.9 \%$ vs. $66.7 \%$ for $I I / I D+R R / R X, p<0.05$ ). 또

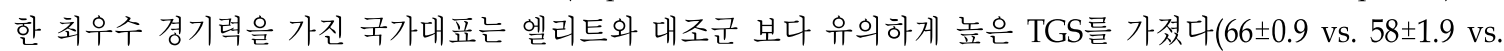
$56 \pm 2.3, p<0.05)$. 이를 근거로 우성조합유전형이 최우수 근력 경기력을 가질 가능성에 대한 승산비는 2.43 배 (CI:1.45-4.09, $p \times 0.001$ )였다. 따라서 $A C E$ 다형성과 $A C T N 3$ 다형성은 한국인에서 근력과 관계된 유전형으로 확인 되었으며, 두 유전자는 상호 조합된 다중유전형에서 근력 경기력에 영향을 줄 것으로 사료된다. 또한 $A C E$ 다형성 과 $A C T N 3$ 다형성을 조합한 다중유전자는 근력 경기력을 예측할 수 있은 유전적 요인으로 사료되었다. 